\title{
Familial renal glucosuria
}

INSERM

\section{Source}

INSERM. (1999). Orphanet: an online rare disease and orphan drug data base. Familial renal glucosuria. ORPHA:69076

Familial Renal Glucosuria (FRG) is characterized by the presence of persistent isolated glucosuria in the absence of both generalized proximal tubular dysfunction and hyperglycemia. FRG is usually considered a benign entity as most patients are not affected by severe clinical consequences. Polyuria and enuresis and later a mild growth and pubertal maturation delay are the only manifestations that have been reported during a follow-up period of 30 years. Episodic dehydration and ketosis during pregnancy and starvation and an increased incidence of urinary tract infections have occasionally been reported in severe cases. FRG is caused by loss-of-function mutations in the gene SLC5A2 (16p11.2). 